\title{
Determination of Ground water potential by electric resistivity method in Rawalakot and adjoining areas of the Sub-Himalayan fold and thrust Belt of Pakistan
}

\author{
Umar Ijaz, Muhammad Yasin* \\ Institute of Geology, University of Azad Jammu and Kashmir, Muzaffarabad, Pakistan *Corresponding Author Email: Rajayasinkhan@gmail.com \\ This is an open access article distributed under the Creative Commons Attribution License, which permits unrestricted use, \\ distribution, and reproduction in any medium, provided the original work is properly cited
}

\section{ARTICLE DETAILS}

Article history:

Received 24 October 2016 Accepted 7 December 2016

Available online 3 January 2017

Keywords:

Sub-Himalayan

Schlumberger, Paraphernalia,

Aquifers.

\section{ABSTRACT}

The study area lies in the Sub-Himalayan fold and thrust belt of Northeastern Pakistan. The electrical resistivity soundings (Schlumberger array) in 24 locations were deployed using ABEM Terameter SAS 4000 (Sweden) with all paraphernalia in the order to explore ground water at considerable depth within formations. The 2D contour maps of apparent resistivity at $30 \mathrm{~m}, 60 \mathrm{~m}$ and $90 \mathrm{~m}$ spacings, transverse resistance and anisotropic contour maps, 2D and 3D maps of aquifer thickness and longitudinal conductance were compiled. The earth resistivity model was formulated by means of IPI2 win software. The qualitative and quantitative interpretation indicates that the investigated area includes confined or semi confined type aquifers beneath sedimentary cover.

\section{Introduction}

The projected area (Fig. 1) forms the Sub-Himalayan fold and thrust belt of North-eastern Pakistan. The water scarcity was the major concern of the research in the area. The research worked aimed at selecting well sites, determination of target drilling depths, evaluation of ground water profile with desired depth classification of aquifer and lithology involved (Asfahani, 2006; Omosuyi et al., 2007). For this purpose, electrical resistivity sounding (ERS) using Schlumberger array was done in the area having recondite places and mountains with their arduous ascents (Fig. 1). The Himalayan orogenic events have deposited a thick cover sequence of sedimentary rocks of Miocene to Recent age in the area (Shah, 2009). These sedimentary rocks include Murree Formation, Nagri Formation, Dhok Pathan Formation and recent alluvium (Table. 2). The lithology of these deposits includes sandstone, shale, siltstone, clays and conglomerates. The sandstone is grey in colour, fine, medium and coarse textured, sheared in places with silicified wood fossils and conglomerate fragments. The siltstone is thick bedded and interbedded with thin to thick beds of shale beds. The clays also form a large region. The rock fragments of igneous, sedimentary and metamorphic origin (quartzite, granite, marble, phyllite, granite gneisses, volcanic and siltstone) are disseminated in few outcrops.

\section{Previous Work}

The earlier workers carried out the geology of few regions (Wadia, 1928; Meddlicot, 1876; Lydekker, 1876; Middlemiss, 1896; Chaudhary \& Ashraf, 1980; Yasin, 2014). However, the Hydrology of the area remained uncertain before present work.

\section{Materials and Methods}

The electrical resistivity soundings (Schlumberger array) in 24 locations were deployed using ABEM Terameter SAS 4000 (Sweden) with all paraphernalia in the order to explore ground water at considerable depth within formations. During resistivity survey, 2 current and 2 potential electrodes ( 4 in all) were deployed in the ground. The current was induced in the ground through current electrodes with the potential difference being measured on potential electrodes following the technique (Dobrin, 1988). In Vertical Electrode Soundings (VES), the symmetric increase in electrode spacing was paced out for deeper depth during quantitative interpretations (Loke, 1999).
(K) with the resistance of reading $(R)$.

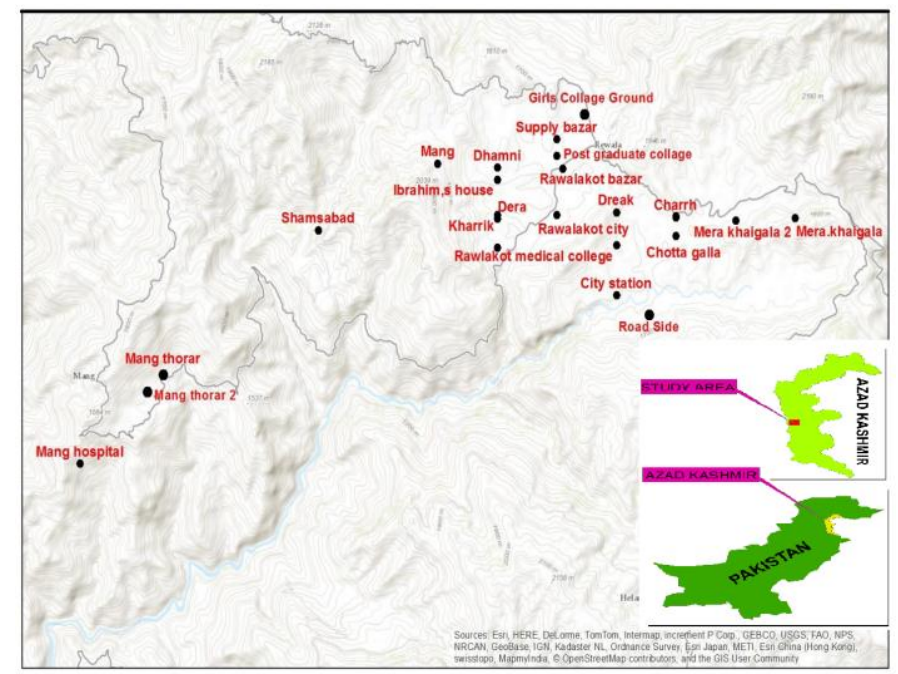

Fig. 1 The location map of Vertical Electric Sounding (VES) stations on the Geographic Information System (GIS). The coordinate's values of each station have been enumerated in the Table. 2. The location of project area is shown towards right hand on map.

The qualitative interpretation based on the curve shapes has categorized the curves (Table. 1: Fig. 11). The true resistivity's as well as thickness of resistivity sites during quantitative interpretations were derived through curve matching techniques. The earth resistivity model was formulated by means of IPI2win software (Zananiri et al., 2006; Sultan et al., 2009). The resistivity $(\rho)$ and thickness (h) in a geoelectric layers were the primary geoelectric parameters. The longitudinal $(\mathrm{S})$, total transverse $(T)$, transverse resistivity $(T / h)$, and anisotropy $(\lambda)$ were the secondary geoelectrical parameters studied in research (Ekwe et al., 2006; Ekwe et al., 2010).

\section{Results and Discussions}

The computer software (Surfer) was helpful in the formation of counter maps by the combining the three-layered materials into $H, K, A$ and $Q$ counter lines. 
The counters having closed lines exhibit local aquifers as compared to the widely-extended contour intervals of regional aquifers. The 2D Contour maps have illustrated the conductivity, resistivity as well as the aquifer thickness (Fig. 5) in area while 3D contour maps illustrate low (depression mark) and high values (peak)

\subsection{D Contour Map of Apparent Resistivity Map at 30m spacing:}

The apparent resistivity values for $30 \mathrm{~m}$ spacing lies between $10.172 \Omega \mathrm{m}$ to $86.897 \Omega \mathrm{m}$. The illustrations are shown in Figure 2. The highest apparent resistivity values (at VES 19, VES 10 and VES 24) have been reckoned as $86.897 \Omega \mathrm{m}, 84.545 \Omega \mathrm{m}$ and $63.792 \Omega \mathrm{m}$ respectively. The lowest measured values $(10.172 \Omega \mathrm{m}, 15.831 \Omega \mathrm{m}, 15.786 \Omega \mathrm{m}, 17.928 \Omega \mathrm{m}, 18.843 \Omega \mathrm{m}$ and $19.779 \Omega \mathrm{m}$ ) have been found at VES $3, \mathrm{VES} 5, \mathrm{VES} 15, \mathrm{VES} 13, \mathrm{VES} 14$ and VES 9 respectively.

Table 1. Showing the field VES locations, Curves Classification and layers.

\begin{tabular}{|c|c|c|c|c|}
\hline 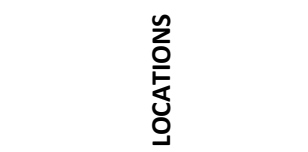 & 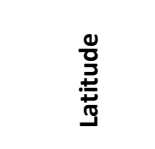 & 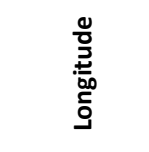 & 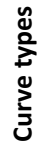 & 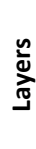 \\
\hline VES 1 Dhamni & $33^{\circ} 51.16 \mathrm{~N}$ & $73^{\circ} 44.55 \mathrm{E}$ & A & 3 \\
\hline VES 2 Kharrik & $33^{\circ} 50.58 \mathrm{~N}$ & $73^{\circ} 44.09 \mathrm{E}$ & $\mathrm{H}$ & 4 \\
\hline VES 3 Rawalakot bazar & $33^{\circ} 51.15 \mathrm{~N}$ & $73^{\circ} 45.12 \mathrm{E}$ & $\mathrm{H}$ & 4 \\
\hline VES 4 Mang & $33^{\circ} 51.21 \mathrm{~N}$ & $73^{\circ} 43.41 \mathrm{E}$ & $A$ & 3 \\
\hline VES 5 Dera & $33^{\circ} 50.53 \mathrm{~N}$ & $73^{\circ} 44.96 \mathrm{E}$ & $\mathrm{H}$ & 3 \\
\hline $\begin{array}{l}\text { VES } 6 \text { CMH Rawalakot } \\
\text { City }\end{array}$ & $33^{\circ} 50.58 \mathrm{~N}$ & $73^{\circ} 45.09 \mathrm{E}$ & $\mathrm{K}$ & 3 \\
\hline $\begin{array}{l}\text { VES } 7 \text { Post Graduate } \\
\text { College Ground }\end{array}$ & $33^{\circ} 51.31 \mathrm{~N}$ & $73^{\circ} 45.35 \mathrm{E}$ & $\mathrm{K}$ & 3 \\
\hline $\begin{array}{l}\text { VES } 8 \text { Girls College } \\
\text { Ground }\end{array}$ & $33^{\circ} 51.49 \mathrm{~N}$ & $73^{\circ} 45.28 \mathrm{E}$ & $\mathrm{K}$ & 3 \\
\hline VES 9 Supply bazar & $33^{\circ} 51.51 \mathrm{~N}$ & $73^{\circ} 45.38 \mathrm{E}$ & $\mathrm{H}$ & 3 \\
\hline VES 10 Shamsabad & $33^{\circ} 50.39 \mathrm{~N}$ & $73^{\circ} 45.40 \mathrm{E}$ & A & 3 \\
\hline VES 11 Chota Galla & $33^{\circ} 50.51 \mathrm{~N}$ & $73^{\circ} 48.35 \mathrm{E}$ & $\mathrm{HA}$ & 5 \\
\hline VES 12 Dreak area & $33^{\circ} 50,61 \mathrm{~N}$ & $73^{\circ} 46.39 \mathrm{E}$ & $\mathrm{H}$ & 3 \\
\hline VES 13 City area & $33^{\circ} 49.59 \mathrm{~N}$ & $73^{\circ} 46.27 \mathrm{E}$ & $\mathrm{K}$ & 3 \\
\hline VES 14 Dreak City area & $33^{\circ} 48.027 \mathrm{~N}$ & $73^{\circ} 38.02 \mathrm{E}$ & $\mathrm{H}$ & 2 \\
\hline VES 15 Rawalakot Airport & $33^{\circ} 50.56 \mathrm{~N}$ & $73^{\circ} 47.52 \mathrm{E}$ & A & 3 \\
\hline VES 16 Charh & $33^{\circ} 50.55 \mathrm{~N}$ & $73^{\circ} 47.32 \mathrm{E}$ & KA & 4 \\
\hline VES 17 Mehrah khaigala & $33^{\circ} 50.54 \mathrm{~N}$ & $73^{\circ} 49.01 \mathrm{E}$ & $\mathrm{H}$ & 3 \\
\hline VES 18 Mehrah khaigala & $33^{\circ} 50.32 \mathrm{~N}$ & $73^{\circ} 47.491 \mathrm{E}$ & $\mathrm{HK}$ & 4 \\
\hline VES 19 Mang Thorar & $33^{\circ} 48.37 \mathrm{~N}$ & $73^{\circ} 38.24 \mathrm{E}$ & $\mathrm{K}$ & 3 \\
\hline VES 20 Mang Thorar & $33^{\circ} 48.32 \mathrm{~N}$ & $73^{\circ} 38.14 \mathrm{E}$ & $\mathrm{K}$ & 4 \\
\hline VES 21 Mang hospital & $33^{\circ} 47.52 \mathrm{~N}$ & $73^{\circ} 37.45 \mathrm{E}$ & $\mathrm{H}$ & 3 \\
\hline $\begin{array}{l}\text { VES } 22 \text { Rawalakot } \\
\text { Medical College }\end{array}$ & $33^{\circ} 50.21 \mathrm{~N}$ & $73^{\circ} 46.01 \mathrm{E}$ & $\mathrm{H}$ & 3 \\
\hline VES 23 Ibrahim house & $33^{\circ} 51.01 \mathrm{~N}$ & $73^{\circ} 44.56 \mathrm{E}$ & $\mathrm{H}$ & 3 \\
\hline VES 24 Ibrahim house & $33^{\circ} 50.18 \mathrm{~N}$ & $73^{\circ} 44.20 \mathrm{E}$ & $\mathrm{HK}$ & 4 \\
\hline
\end{tabular}

Table 2. Local stratigraphy of the study area.

\begin{tabular}{|l|l|l|}
\hline Formation & Age & Description \\
\hline $\begin{array}{l}\text { Alluvial } \\
\text { Terraces }\end{array}$ & Recent & $\begin{array}{l}\text { Unconsolidated deposits of clay, silt, } \\
\text { gravel. }\end{array}$ \\
\hline $\begin{array}{l}\text { Dhok Pathan } \\
\text { Formation }\end{array}$ & $\begin{array}{l}\text { Late } \\
\text { Miocene }\end{array}$ & $\begin{array}{l}\text { Gray, fine to medium grained, } \\
\text { medium to thick bedded sandstone } \\
\text { with clay and siltstone. Sandstone } \\
60 \% \text { and clays 40\%. }\end{array}$ \\
\hline $\begin{array}{l}\text { Nagri } \\
\text { Formation }\end{array}$ & $\begin{array}{l}\text { Late } \\
\text { Miocene }\end{array}$ & $\begin{array}{l}\text { Greenish gray to light gray, massive, } \\
\text { medium to coarse gained sandstone, } \\
\text { siltstone and mudstone. The } \\
\text { sandstone alternate with clays. It } \\
\text { includes 40\% clays and 60\% } \\
\text { sandstone. }\end{array}$ \\
\hline
\end{tabular}

\begin{tabular}{|c|c|c|}
\hline ............... & Fault & 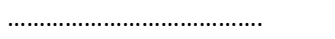 \\
\hline $\begin{array}{l}\text { Murree } \\
\text { Formation }\end{array}$ & $\begin{array}{l}\text { Early } \\
\text { Miocene }\end{array}$ & $\begin{array}{l}\text { Clays, shales and sandstone. } \\
\text { Sandstone is fine to medium } \\
\text { grained. }\end{array}$ \\
\hline
\end{tabular}

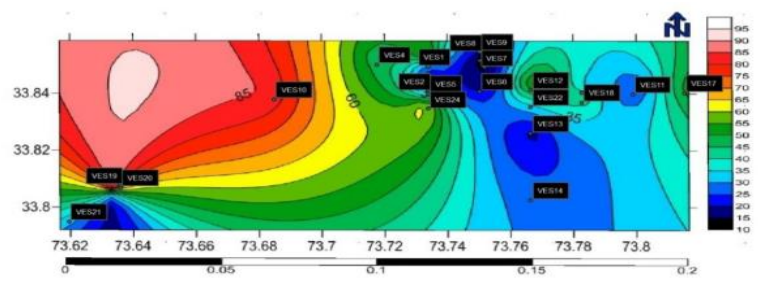

Fig. 2 The 2D contour map of apparent resistivity at 30m spacing.

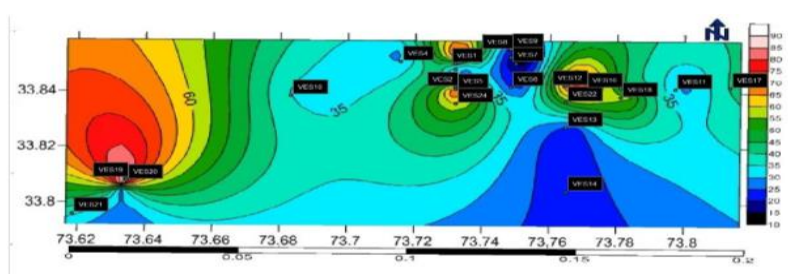

Fig. 3 The 2D contour map of apparent resistivity at $60 \mathrm{~m}$ spacing.

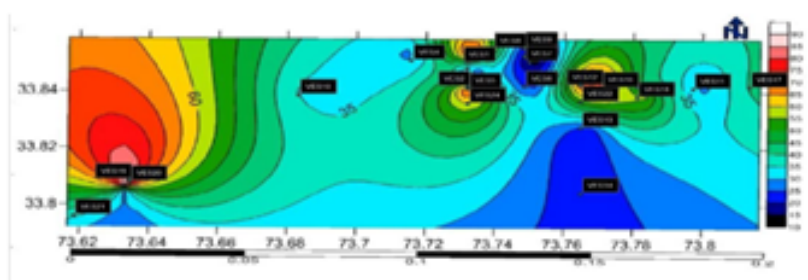

Fig. 4 The 2D contour map of apparent resistivity at 90m spacing.

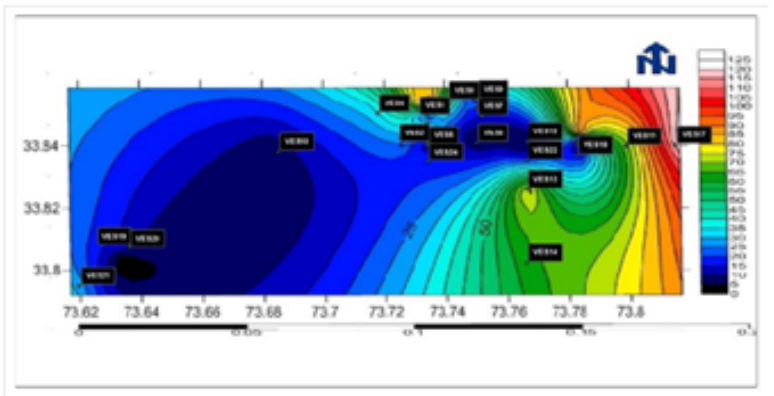

Fig. 5 The2D contour map of aquifer thickness.

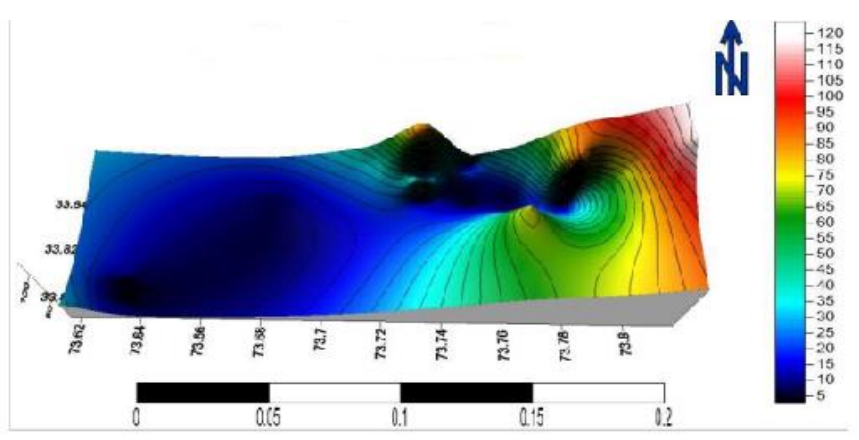

Fig. 6 The 3D contour map of aquifer thickness. 


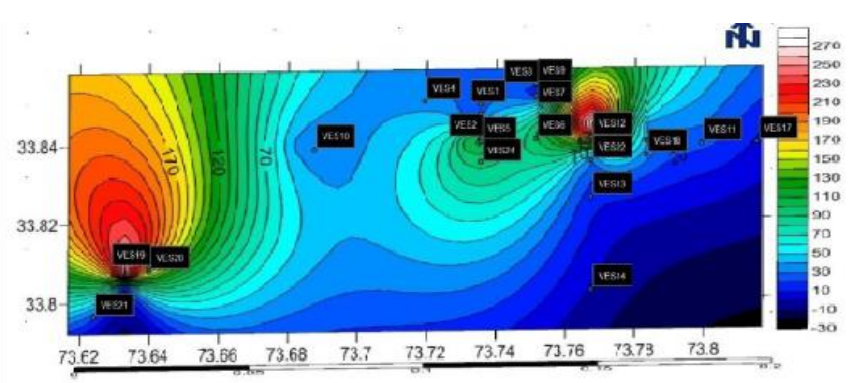

Fig. 7 The 2D contour map of transverse resistance.

\subsection{D Contour Map of Apparent Resistivity at 60m spacing}

The apparent resistivity for $60 \mathrm{~m}$ spacing falls between $7.9567 \Omega \mathrm{m}$ to 88.446 $\Omega \mathrm{m}$ and corresponding contour map is illustrated in the Figure 3 . The highest apparent resistivity values (88.446 $\Omega \mathrm{m}, 80.919 \Omega \mathrm{m}$ and $80.919 \Omega \mathrm{m}$ ) have been recorded at VES 19 , VES1 and VES 12 respectively. The lowest apparent resistivity values (7.9567 $\Omega \mathrm{m}, 19.583 \Omega \mathrm{m}, 20.2 \Omega \mathrm{m}$ and $20.66 \Omega \mathrm{m}$ ) have been noticed at VES 3, VES 13, VES 7 and VES 12 respectively.

\subsection{Contour Map of Apparent Resistivity at 90m spacing}

The apparent resistivity for $90 \mathrm{~m}$ spacing ranges from $7.36 \Omega \mathrm{m}$ to $94.254 \Omega \mathrm{m}$. The corresponding contour map is shown in Figure 4. The highest apparent resistivity values $(94.254 \Omega \mathrm{m}, 81.922 \Omega \mathrm{m}$ and $65.043 \Omega \mathrm{m})$ have been found at VES 19, VES 24 and VES 1 respectively. The lowest apparent resistivity values (7.36 $\Omega \mathrm{m}, 16.776 \Omega \mathrm{m}, 19.216 \Omega \mathrm{m}$ and $19.898 \Omega \mathrm{m}$ ) are reckoned at VES 3, VES13, VES 8 and VES 7 respectively.

\subsection{D and 3D Contour Map of Aquifer Thickness:}

The volume of water at each VES station heavily relies on respective aquife thickness. The entire region has been categorized into good, moderate as well as poor ground water potential zone (Fig. 5). The 70 to $100 \mathrm{~m}$ thickness in the area revealed that the production water bearing zones are good potential zones at North eastern and central portion of study area. Amongst these Dhamni, City Station, Merah, Khaigala and Chotta Galla with $96.4 \mathrm{~m}, 78.7 \mathrm{~m}, 73.9 \mathrm{~m}$ and $72.1 \mathrm{~m}$ thickness respectively are prominent. The moderate ground water potential zone has an aquifer thickness of 40 to $70 \mathrm{~m}$. Kharrik and Supply Bazar fall in this category. The remaining parts of the area were demarcated as a very low saturated zone with an aquifer thickness less than $40 \mathrm{~m}$.

The 3D map depicts the highest aquifer thickness values at VES 1 and VES 13 in central portion of study area as compared to the lowest thickness values in the remaining area (Fig. 6).

\subsection{D Contour Map of Transverse Resistance:}

Transverse resistance ( $T$ ) is the total resistance through I m column cut perpendicular to the plane and is defined in terms of ohm $/ \mathrm{m}$. The high values of transverse resistance at VES 5, VES12 and VES 19 in central, south western portion of study area is shown on $2 \mathrm{D}$ map (Fig. 7). The map indicates a low value of transverse resistance in the remaining part of area.

\subsection{D and 3D Contour Map of Longitudinal Conductance:}

The longitudinal conductance is defined in terms of ratios of different layers to their respective resistivity's. The Longitudinal conductance determines the properties of a conducting layer in contrast with the transverse resistance determining the characteristics of resisting layer (Yungul, 1996). The Fig. 8 depicts the total longitudinal conductance contour map. The conductance values falls between -1 Siemens to 20 Siemens. The highest longitudinal conductance values of 19.8, 7.58, 5.09 and 4.59 Siemens correspond with VES3, VES14, VES13 and VES15 respectively. The lowest conductance values of 0.0352 and 0.1195217 Siemens correspond with VES 6 and VES 9 respectively (Fig. 8). The conductance values increases towards central and north eastern part of contour map. Increase in conductance automatically results in decrease in resistivity reflecting presence of the ground water potential aquifers (Gowd, 2004).

The 3D maps display two low peaks representing the highest conductance at VES3 and VES 14 in central northern portion of study area (Fig. 9). The rest of the areas are indicated by lowest anisotropy values.

\subsection{Contour Map of Anisotropy:}

The Figure 10 represents of coefficient of anisotropy of the study area. The coefficient of anisotropy values $(\lambda)$ lies between -0.6 to 4.4 . The high values observed in the north western and central part of the study area needs to be precise at VES 20 and VES 12, while the remaining part is characterized by low values coefficient of anisotropy. In general, high value of coefficient of anisotropy $(\lambda)$ reveals near surface inhomogeneity of materials within the subsurface [18 and 19] such as the topsoil and weathered or partially weathered layer that could not support groundwater development (Kumar et al., 2007; Yilmaz, 2011). The low values of coefficient of anisotropy $(\lambda)$ falls unequivocally between-0.0352 to 0.6 .

\subsection{Interpretation of Lithological Columns}

The interpretation of VES curves (Fig. 11) can aids us to developed lithological columns in quantitative interpretations.

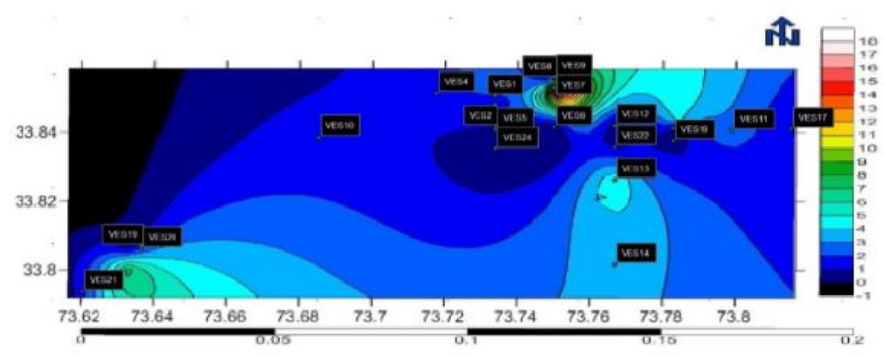

Fig. 8 The 2D contour map of longitudinal conductance.

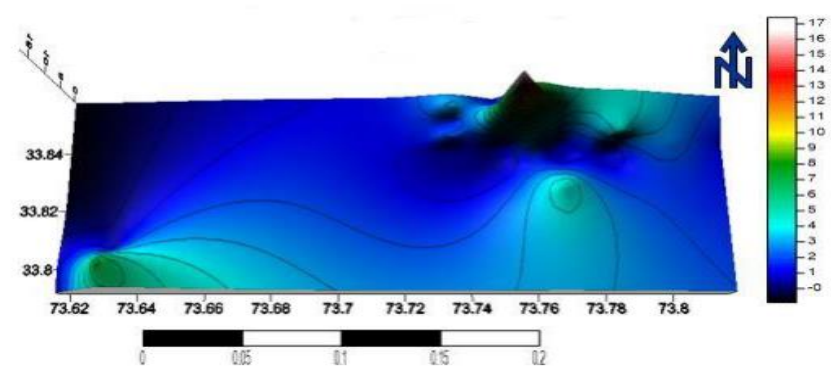

Fig. 9 The 3D contour map of longitudinal conductance

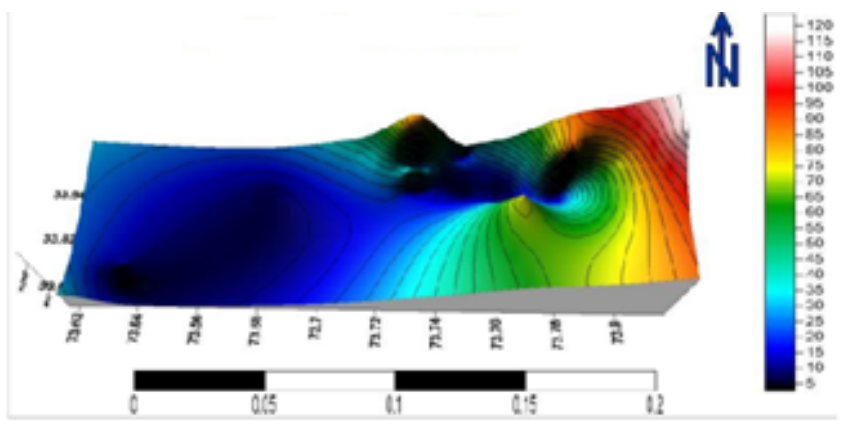

Fig. 10 The 2D contour map of anisotropy.
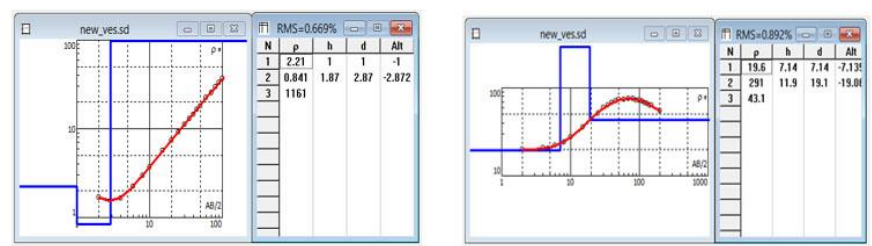

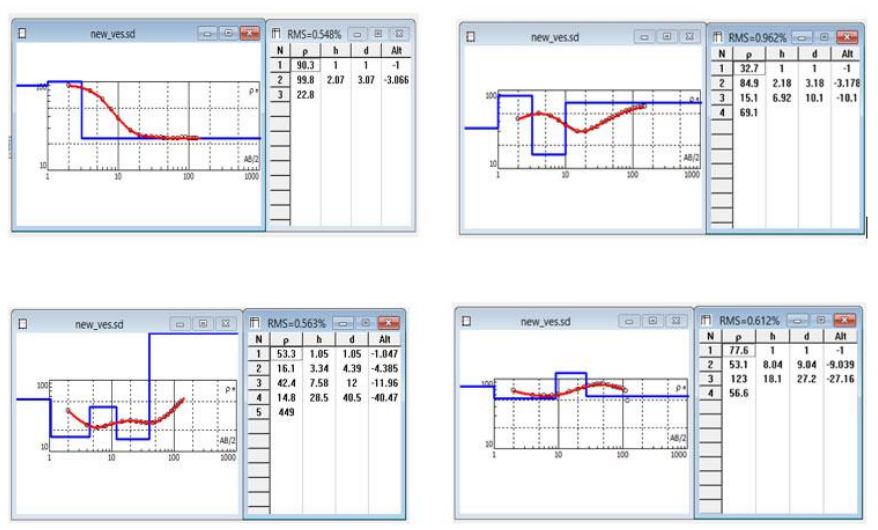

Fig. 11 The different types of VES curves. The curves indicates that the aquifers are both confined and semi-confined type, which are not recommended for tube well purposes because there is no regional aquifer present in the study area but dug wells can be installed.

The Reawaked and adjoining areas include river deposited Miocene sediments underlying alluvium. The subsurface strata and water bodies mapped by resistivity techniques were analyzed by means of hydrogeological and other geoelectrical parameters. The interpretations were helpful in the determination of subsurface lithological units and location of aquifer sites. The area is medium to high in resistivity and dominated by $\mathrm{H}$ and $\mathrm{K}$ type curves (Table. 1; Fig. 11). The resistivity values increase as the particle size is deviated from sand to boulder.

The near surface materials are dominated by clays as well as sandy materials and alluvium. Some points possess high resistivity values due to moisture content in the near surface material. The field resistivity data is interpreted to find the lithologies (boulders, sand and clays overlying the area). The resistivity curves include $H, Q, K A$ and HA types (Fig. 11).

The aquifers are both confined and semi-confined and seasonally recharged by high rainfall. The major recharging agents are rain, springs, and intermittent streams. According to careful evaluation the average rainfall is $1000 \mathrm{~mm}$ to $2000 \mathrm{~mm}$ per year and the mountains are covered with snow during winter. The area is parched by the sun during summer and the streams are in spate during summer monsoon.

\section{Conclusions}

On the basis of the qualitative and quantitative interpretation of the geophysically prospected sites it was concluded that the area under investigation is mainly composed of sedimentary rocks. Lithologic ally main components are clays, siltstone, mudstone, sandstone etc. The aquifers can be designated as confined and semi confined. As obvious from quantitative interpretation, the presence of alluvium and low resistivity values represent the presence of ground water.

\section{References}

[1] Asfahani, J., (2006). Neogene aquifer properties specified through the interpretation of sounding data, salameyeh region Syria. Hydro Pro, Inc, 21: 2934-2943.

[2] Chaudhary, M. N., Ashraf, M., (1980). The volcanic rocks of Poonch district, Azad Kashmir. Special Issue, Geology Bulletin University of Peshawar, 13: $121-128$.

[3] Dobrin, M. B., (1988). Introduction to Geophysical Prospecting. New York: McGraw-Hill, pp. 867.

[4] Ekwe, A.C., Onuoha, K.M., Onu, N.N., (2006). Estimation of aquifer hydraulic characteristics from electrical sounding data: The case of middle Imo river basin aquifers, southeastern Nigeria. Journal of Spatial Hydrology, 6 (2):121-131.

[5] Ekwe, A.C., Onuoha, K.M., Ugwumbah, K.I., Onwuka, O.S., (2010) Estimation of aquifer hydraulic characteristics of low permeability formation from resounding data: The case of Oduma town, Enugu state. Journal of Earth Science, 4 (1) :19-26.
[6] Gowd, S. S., (2004). Electrical resistivity survey to delineate the ground water potential aquifers in Peddavanka watershed, Anantapur District, Andhra Pradesh, India. Springer Link Environmental Geology, 46(1): 118-131.

[7] Kumar, D., Ahmed, S., Krishnamurthy, N. S., Dewandel, B., (2007). Reducing ambiguities in vertical electrical sounding interpretations: A geostatistical application. Journal of Applied Geophysics, 62 (1): 16-32.

[8] Loke, M. H., (1999). Electrical imaging surveys for environmental and engineering studies. A practical guide to 2D and 3D surveys: Austin, Texas. Advanced Geoscience, Inc, pp. 57.

[9] Lydekker, R., (1876). Notes on geology of the Pir Panjal and neighboring Districts. Records of the Geological Servey of India, $9: 155$.

[10] Meddlicot, H. B., (1876). Notes on the sub-Himalayan series of Jammu Hills. Records of the Geological Survey of India, 9:49.

Middlemiss, C. S., (1896). The geology of Hazara and black mountains. Memoirs of the Geological Survey of

India, 26: 302.

[11] Omosuyi, G.O., Adeyemo, I.A., Adegoke, A.O., (2007). Investigation of groundwater prospect using geoelectric and electromagnetic sounding at Afunbiowo near Akurea, Southwestern Nigeria. Pacific Journal of Science and Technology, 8(2): 172-182.

[12] Shah, S.M.I., (1928). Stratigraphy of Pakistan. Memoirs of the Geological Survey of Pakistan, 22: 293-298.

[13] Sultan, S.A., Mekhemer, H.M., Santos, F.A.M., Abd Alla, M., (2009). Geophysical measurement for subsurface mapping and groundwater exploration at the central part of Sinai Peninsula. Arabian Journal for Science and Engineering. 34 (1A): 103-119.

[14] Wadia, D. N., (1928). The geology of the Poonch state (Kashmir) and adjacent portions of the Punjab. Memoirs of the Geological Survey of India, 51(2): 185-370.

[15] Yasin, M., (2014). Petrography and Sedimentology of Neogene sediments in Mang and adjoining areas in the Sub-Himalayas, Azad Jammu and Kashmir, Pakistan, Unpublished MS Thesis, University of Azad Jammu and Kashmir, Muzaffarabad, pp. 213.

[16] Yilmaz, S., (2011). A case study of the application of electrical resistivity imaging for investigation of a landslide along highway. International Journal of Physical Science, 6(24): 5843-5849.

[17] Yungul, S. H., (1996). Electrical methods in geophysical exploration of sedimentary basin. Chapman and Hill, U.

[18] Zananiri, I., Memou, T., Lachanas, G., (2006). Vertical electrical sounding survey at the central part of the Kos Island, Aegean, Greece. Geoscience, 411-413. 